\title{
AUDIOBOOK FOR INCLUSIVE STUDENTS: ITS EFFECTIVE PRACTICE
}

\author{
Rizky Amalia Utomo; Faizatul Istiqomah \\ Institut Agama Islam Negeri (IAIN) Ponorogo; \\ Institut Agama Islam Negeri (IAIN) Tulungagung
}

\begin{abstract}
The purpose of this study is to describe audiobook as learning media and to describe factors influencing the successful used of audiobook by the blind students in inclusive school. This study was conducted at MA Muhammadiyah 1 Ponorogo. The instruments were observation, interview, and documentation. The result of this study revealed that the process of the use audiobook for supporting references in learning English, the teacher introduces an audio application and then installing it on a blind students' hand phone or laptop. The factor influencing the successful use of audiobook by the blind students there are two factors that are internal and external factor. Internal factor that influencing the success of blind students in English learning by using audiobook the existence of enthusiasm from within. External factor that from parents, teacher, caregivers, and also their friends. All of them always help the blind students when needed.
\end{abstract}

riskyli62@gmail.com

Key word: audiobook, learning media, blind students, inclusive school

\section{INTRODUCTION}

In Indonesia, English is adoption as the foreign language. It is include in curriculum education that every school runs. It becomes a local content in Elementary school, a compulsory subject in Junior School and Senior High School and a complementary subject of the higher education institution (Natria, 2007).

Education is a basic right for all citizens without exception. It can be found in the 1945 constitution of Indonesia, article 31(1), which states that every citizen has the right to get proper education and teaching accessibility. It includes everyone, no matter their religions, wealth, ability, and ethnicity. Law no. 20 of 2003, on National Education System, chapter 4, article 5, paragraph 1 and 2 also states that every citizen has the same right and opportunity to acquire qualified education. Besides, citizens who have special needs such as physical, emotional, intellectual and social disabilities are entitled to obtain special education. It means that people with disabilities have the same right as other people to study through inclusive education (Aryanti, 2014).

In Indonesia has been regulated in law no.8 of 2016 concerning persons with disabilities. Recognize that disability is an evolving concept and disability is the result of interactions between people with limited abilities and attitudes and 
the environment that hinders their full and effective participation in society based on equality with others (Appendix Act 19 of 2011 concerning Ratification of the CRPD , opening translation of CRPD letter (e) Recognizing that disability is an evolving concept and that disability results from the interaction between persons with impairments and attitudinal and environmental barriers that hinders their full and effective participation in society on an equal basis with others, (Convention on the Rights of Persons with Disabilities), Preamble, CRPD.

Fundamental principles, practices, educational material and teaching aids used to teach various subjects to students with special needs are few and far between. In some cases, material has been prepared for internal use at specialized schools or in other closed environments. In other cases, knowledge has been passed from teacher to teacher as part of workplace training. No systematic material on pedagogical principles, practices, educational material and teaching aids exist for areas such as teaching first language teaching, foreign language teaching, mathematics and music for the blind. The project has collected and collated information on good inclusion practices in five select areas (teacher skills, alternate media, and support structures, preparation for inclusion and teaching environment.

According to Cynthia Ann Bowman (2004) disabilities the right to receive a free appropriate public education in the most integrated setting possible. Equal access to, and subsequent success in, education is the gateway to changing many other areas of life for individuals with disabilities. It is necessary to first recognize the difficult journey to the legal right of integration.

For persons who are blind, learning a foreign language can further reduce the gap that is caused by the vision loss and at the same time increase recreational opportunities. More specifically, it enables persons who are blind to access different kinds of media. a foreign language can allow a person who is blind to access various e-books and audio books widely available on the internet.

Based on the research by Andi Hamzah Fansury (2019) audiobooks are educational materials that blind learners can use in every situation and every time without being tied to any place or without other people's help. Audiobooks produced for blind learners can create an environment to provide, enrich, inform, guide and teach subjects fully by creating an environment to learn and also develop independent learning skill to solve problems and answer questions as well as discuss different course related topics.

Learning process in inclusive class based on reality in the field the teacher still use the same learning method as other normal students, but at the end of the learning the teacher has an approach for blind students.

Based on descriptive above, researcher will know audiobook as English learning media is used by the blind inclusive school students of MA Muhammadiyah 1 Ponorogo. 


\section{METHODS}

In this research, the researcher uses qualitative research method. Data were collected through observation, interview, and documentation. In this study the researcher acts as a key instrument, full participant as well as data collectors, while other instruments are supporting and the presence of the researcher is known by the informant. So, by directly attending the researcher can interact socially with the school principal, English teacher, blind students, and related parties to get data about audiobook as English learning for blind students at MA Muhammadiyah 1 Ponorogo with full observation as a researcher. The result of data collection was analyzed by the following steps, namely data reduction, data display and drawing conclusion.

\section{FINDING AND DISCUSSION}

1. Audiobook as English Learning Media Used by The Blind Inclusive School Students at MA Muhammadiyah 1 Ponorogo

Inclusive education means education where all students are equal participants in the learning process. Provision of inclusive education is based on the belief that those with disabilities should not have to depend on specialized services alone to benefit from educational resources, activities and practices that are otherwise available to all (Julka, 2015).

The school accommodates all children regardless of physical, intellectual, social, emotional, or other condition. Because every child has the right to gets proper education. As an MA Muhammadiyah 1 Ponorogo is a school that accommodates children who have special needs. So that in learning tailored to the needs of children instead of children who are adapted to the speed and nature of the learning process.

Before we know more about teacher's teaching English at inclusive class, first we must understand the condition and situation of students in the class. In MA Muhammadiyah 1 Ponorogo it organized an education system that has normal students and blind students in one class, in term of application, preparation, and regarding the learning model. In MA Muhammadiyah 1 Ponorogo is not much difference between normal students and blind students, however in teaching and learning activities that distinguish between normal students and blind students is from the approach taken by the teacher during the learning activities. According to Stella Olivia (2015) "teachers are required to collaborate with other professions or human resources in planning, implementation, and evaluation. The approach for the blind students is to reread the material to them, the teacher explains the material in near blind students. In this case the teacher would explain about message the short text directly translated by the teacher, because blind students are limitation of physic, they would have difficulty in interpret of main the text. Sometimes the teacher asked to blind 
Available online at https://jurnal.iainponorogo.ac.id/index.php/eltall

students to wrote the message in braille after listening to the teacher's explanation. Another approach used by the teacher is to introduce audio applications which are installed on hand phone or laptop for blind students to study in class or outside the classroom.

As submitted by Andi Hamzah Fansury (2019) there is an audiobook can be used by the blind student in the classroom or at home, to give them access to books, documents, exercises and other material either existing or adopted in any digital. Based on Andi's definition "audio books have been used to teach children to read, as a method for the blind to have access to books, and as a learning format for everything from learning a foreign language, guitar lessons, motivational seminars, and cooking lessons. The self-help industry utilizes audio books to tape workshops, conferences and basically uses them as a learning tool.

2. Factors Influencing Successful Used of Audiobook by The Blind Inclusive School Students at MA Muhammadiyah 1 Ponorogo

Audiobook media that used in English learning process always had successful to blind students. The observation and interview with blind students of MA Muhmmadiyah 1 Ponorogo had some factor influencing as the reason for using audiobook.

In every learning process that is done certainly not always run smoothly. In every learning there must be various problems that interfere, hinder, complicate or even lead to failure in achieving the learning objectives. But in this school MA Muhammadiyah 1 Ponorogo keep trying to find ways to succeed the blind students, so that no blind students are left behind in learning, especially in English learning, various ways have been done starting from the approach as has been done by teacher. The teacher used the approach by explaining or reread the material for blind students, because for teacher all students who were taught had to understand the material as a whole, so as not to be left behind. Another way here the school is invited to work together with the orphanage in making learning successful by introducing an audio application and then installing it on a blind students' hand phone or laptop. So that can make it easier for the blind students to understand the material that has been taught without having the teacher repeat the material many times.

The factor of influencing successful in English learning by used audiobook, which is two factors: factor internal and external. They are factors which come from inside the individual. According to $\mathrm{H}$ D Brown (2007) these factors are specified by the individual students like motivation, attitude, personal practice and study habits. Each of these factors is an individual element of learners' ability to acquire a foreign language but each component also interacts with another. They are factors that come from 
Available online at https://jurnal.iainponorogo.ac.id/index.php/eltall

outside the individual. Based on H D Brown (2007) external factors can be different for each individual, but their common attribute is that they are based solely on the circumstances outside of the control and influence of the learner".

Internal factor that influencing the success of blind students in English learning by using audiobook the existence of enthusiasm from within. They follow the lesson they sitting in front. They appear to be active when attending the lesson, sometime they also ask and give opinions.

In the learning blind students needed encouragement or motivation. In addition, another internal factor needed also external factor. On external factors they are numbering of point to help blind students, so that learning is successful namely: family factor and community factor. These factors help the blind students in learning are from the support and encouragement of the family and the teacher. The way parents and teacher educated and pay attention to their students will affect success in learning.

\section{CONCLUSION}

The process of the used audiobook for supporting references in learning English, the teacher introduces an audio application and then installing it on a blind students' hand phone or laptop. For our laptops, we installed NVDA and for the hand phones, we put talk back and smart voice. After the application is installed on the hand phone or laptop the blind students are activated and they can use directly. Here blind students can choose the material what they need to learn, they can learns through the internet by using Google or web to search for e-books related to the material in finding material they use the help of audio applications, so they can search for himself without the need for help from her friends.

The factor influencing the successful use of audiobook by the blind students there are two factors, that are internal and external factor. Internal factor that influencing the success of blind students in English learning by using audiobook the existence of enthusiasm from within. External factor that from parents, teacher, caregivers, and also their friends. All of them always help the blind students when needed.

The successful of using audiobook as media for students in learning English at MA Muhammadiyah 1 Ponorogo are providing opportunities for students to learn language by utilizing and practicing the material in all composition of learning language.

\section{REFERENCES}

Abery, Brian H. Inclusive Education Strategy: A Textbook USA: UNICEF Armenia, 2018. 
Amstrong, Derrick "Inclusion: by Choice or by Chance?", Inclusive Education. University of Sydney Library: Routledge Taylor and Francis Group, 2011: 29-39.

Anonym. Teaching The Blind Foreign Language. Europe: Erasmus.

Aryanti, Widya "Difficulties In Learning English Faced By Visual Impaired Students At Center Of Language Development (P2b) In State Islamic University (Uin) Sunan Kalijaga", Inclusi. Yogyakarta: UIN Sunan Kalijaga, 2014: 190-206.

Bowman, Cynthia Ann. et.al., A Guide to High School Success for Students with Disabilities. London: Greenwood Press, 2004.

Bown, H. D. Principles Of Language and Teaching. USA: Pearson Education Internasional, 2007

Denzin, Norman K. and Lincoln, Yvona S. The SAGE Handbook of Qualitative Research. California: SAGE Publication Inc, 2018.

Downes, Brenda and Miller, Stave. Media Studies. UK: Teach Yourself Book, 1998.

Fansury, Andi Hamzah. et.al., "Audiobook As Teaching Media To Blind Students In Learning Efl”, Education, Language Teaching, and Science. Makasar: Bosowa University, 2019: 1-9.

Hatch, J Amosh. Doing Qualitative Resarch In Education Setting. New York: Albani, 2002.

Heinich, Robert et.al., Intructional Media and Technology for Learning. Columbus: Macmillan Publishing Company, 1982.

Julka, Anita. Including Children With Special Needs Upper Primary Stage. New Delhi: National Council of Educational Research and Training, 2015.

Media

Communication,

(online), https://en.m.wikipedia.org/wiki/Media (communication) accessed Thursday 23 April 2020.

Natria, Ima. "Students Errors In Using Simple Present Tense In Writing Descriptive Texts The Case Of The Eight Year Students Of SMPN 2 Brebes In Academic Year 2006/2007",Thesis, UNNES, Semarang, 2007.

Olivia, Stella.Menuju Pendidikan Inklusi Panduan Praktis Untuk Mengajar Edisi Ketujuh. Yogyakarta: Pustaka Pelajar, 2015.

Ozgur, Aydin Ziya. and Gurcan, Halil Ibrahim. "An Audiobook Project For Blind Students At The Open Education System Of Anadolu University", Educational Technology. Turkey: Anadolu University, 2004: 3-10.

Rosada, Admila et.al., Menjadi Guru Kreatif Praktik-praktik Pembelajaran di Sekolah Inklusif. Yogyakarta: PT Kanisius, 2018.

Stake, Robert E. Qualitative Research : Studying How Things Work. United State of America: The Guilford Press, 2010.

UU 8 tahun 2016 tentang penyandang disabilitas, (online), https://www.jogloabang.com/pustaka/uu-8-2016-penyandangdisabilitas accessed on Sunday 19 January 2020. 